\title{
Optimization of biogas production by co-digestion of organic waste (cow dung and water hyacinth)
}

\author{
Alfred D. DOHOU *1,2,3, KOTO N'GOBI Gabin ${ }^{1,2,3}$, Clément A.KOUCHADE ${ }^{1,2,3}$, Basile B. \\ KOUNOUHEWA ${ }^{1,2,3}$

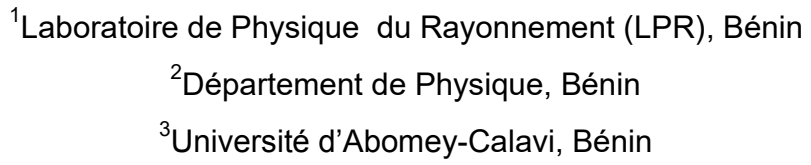

\begin{abstract}
The objective of this work is to determine the co-digestion ratio of water hyacinth and cow dung for the optimization of biogas production at Sô Ava, a lake city of Southern Benin. To achieve these ratios, we suppose that the water hyacinth has a high gas yield and cow dung ensures stability in the biodigester because it brings fresh bacteria and has a strong buffering capacity (maintenance of a stable $\mathrm{pH}$ ). For 45 days, we have introduced a mixture of water hyacinth and cow dung in 5 mini-biodigesters of 10 liters each: digester $n^{0} 1$ ( $100 \%$ of cow dung); digester $n^{\circ} 2$ ( $100 \%$ of the water hyacinth); digester $n^{\circ} 3(50 \%$ of the water hyacinth and $50 \%$ of the cow dung); digester $n^{\circ} 4$ (75\% of cow dung and $25 \%$ of water hyacinth); digester $n^{\circ} 5$ ( $75 \%$ of the water hyacinth and $25 \%$ of the cow dung). The measurements of the $\mathrm{pH}$, temperature and the proportion of gas $\left(\mathrm{CH}_{4}, \mathrm{CO}_{2}, \mathrm{O}_{2}\right.$ and $\left.\mathrm{H}_{2} \mathrm{~S}\right)$ in the mini-biodigesters was done. The measurements show that the digester $n^{\circ} 5$ produces the highest capacity of $15.24 \mathrm{~L}$ of biogas with $70 \%$ of methane while the digester $n{ }^{\circ} 2$ has the lowest capacity $5.47 \mathrm{~L}$ of biogas with $58 \%$ methane. These results show that the yield of biogas produced is greater when using the mixture of the substrate with the ratio of $75 \%$ of water hyacinth and $25 \%$ of cow dung. This result encourages the energy recovery from water hyacinth, once considered as a seasonal plague which hinders navigation of local boat in the lake.
\end{abstract}

Keywords: co-digestion, cow dung, water hyacinth, optimization

\section{Introduction}

Anaerobic digestion is the biochemical process of producing biogas by transforming complex organic materials into a clean, renewable source of energy. The co-digestion process is a reliable alternative process which is used to solve the environmental drawbacks of the substrate management. The use of co-substrates generally improves biogas yields due to the positive synergies established during the digestion process and the supply of missing nutrients by the co-substrates [1]

Several studies have been carried out on the production of biogas using different biomasses as mono-substrates [2],[3]. However, the direct use of substrates is difficult due to their nutritional imbalance, which usually lack of microorganisms and the effect of operational factors. The process of co-digestion has been recommended to overcome these difficulties [4]. Anaerobic co-digestion has been widely used to improve biogas production. A number of published articles have investigated co-digestion in recent years. Astals et al [5] studied the co-digestion of livestock manure with other different biomasses to improve biogas production rates [6] reported that the combination of whey and poultry manure was found to be able to 
maintain the correct $\mathrm{C} / \mathrm{N}$ (Carbon to nitrogen ratio) ratio in the reactor. According to Murto et al (2004) [7], a highly buffered system was obtained by co-digestion of solid wastes, manure, fruit and vegetable waste. The process worked well with a gas yields reaching $0.8 \mathrm{~m}^{3} \mathrm{~kg}^{-1}$ of dry matter. Somayaji et al [8] conducted a study with digesters fed with cow manure and varying proportions of wheat straw and concluded that the highest specific methane yields were observed with $40 \%$ straw of wheat total solids in the raw material. Ghaly et al [9] studied a $155 \mathrm{~L}$ two-stage, two phases unmixed anaerobic reactor for treating whey with dairy manure and concluded that the $\mathrm{pH}$ should be controlled the methanogenic phase; otherwise the production of biogas was not possible. The anaerobic co-digestion of grass silage, sugar beet tops and oat straw with cow manure was evaluated by Lehtomaki et al [10] in continuously stirred tank reactors. In the laboratory supplied semi-continuously.

Gelegenis et al [11] reviewed a series of laboratory experiments in continuously stirred tank reactors under mesophilic conditions, semi-continuously filled with various mixtures of diluted poultry manure and whey. Co-digestion of whey with manure has been shown to be possible up to a $50 \%$ participation of whey (by volume) in the daily feed mixture without any addition of chemicals. Anaerobic co-digestion of sludge from grease traps and sewage sludge has been successfully performed in both laboratory batch trials and pilot scale continuous digestion trials [12]. The possible use of the potato tuber and its industrial byproducts (potato tubs and potato skins) for farm-scale co-digestion with pork manure was examined in laboratory by Kaparaju and Rintala [13]. The results showed that the potato tuber and its industrial by-products can be co-digested with pig manure at a loading rate of 2 $\mathrm{kg} \mathrm{VS} \mathrm{m}^{-3}$ day $^{-1}$ in continuously stirred tank reactors at $35^{\circ} \mathrm{C}$. The proportion of waste in the mixture appears to be large and the feed may contain at least $15-20 \%$ potato waste.

Zupancic et al [14] carried out a large-scale experiment on the co-digestion of organic waste from household waste (swill) with municipal sludge. The results showed that anaerobic digestion is the solution to the handling of organic waste (swill) and above all it is very beneficial with little negative impact on the environment. An $80 \%$ increase in the amount of biogas was also observed. The potential of semi-continuous mesophilic anaerobic digestion for the treatment of solid waste, fruit-vegetable waste and manure in a co-digestion process has been experimentally evaluated and presented by Alvarez et al [15]. They found that a combined treatment of different types of waste such as manure (cattle and pigs), solid waste from slaughterhouses (rumen, rumen and blood of cattle and pigs) in a mesophilic codirection process gives the possibility of treating waste, which cannot be treated separately. The feasibility of anaerobic co-digestion of mixed industrial sludge with municipal solid waste was investigated in three simulated anaerobic landfill bioreactors over a period of 150 days [16]. They concluded that the anaerobic co-digestion of industrial sludge with organic wastes is a feasible process in waste stabilization and in the treatment of leachate releases from simulated anaerobic reactors. Gomez et al [17] presented the results obtained for the digestion of primary sludge and the co-digestion of this sludge with the fruit and vegetable fraction of municipal solid waste under mesophilic conditions. The co-digestion of the fruit and vegetable fraction of municipal solid waste with the primary sludge produced more biogas than the digestion of the primary sludge, due to the higher concentration of volatile solids contained in this feed. The feasibility of anaerobic co-digestion of five coffee wastes from the production of coffee and sewage sludge was assessed by Neves et al [18]. Methane yields of between 0.24 and $0.28 \mathrm{~m}^{3} / \mathrm{kg}$ of VS were obtained with the exception of a barleyrich waste which only reached $0.02 \mathrm{~m}^{3}$ of $\mathrm{CH}_{4} / \mathrm{kg}$ of VS. Fezzani et al [19] studied for the first time the thermophilic anaerobic $\left(55^{\circ} \mathrm{C}\right)$ co-digestion of oil mill wastewater with solid waste from oil mills in semi-continuous tubular digesters at laboratory scale. They concluded that wastewater from oil mills could be successfully degraded by co-digestion with solid waste from oil mills under thermophilic conditions without prior dilution and without the addition of nitrogenous chemicals. The co-digestion of onion juice and aerobic wastewater sludge produced by an onion processor using an anaerobic mixed biofilm reactor was investigated by Romano et al [20] for the potential for biogas energy production and waste treatment. 
Several articles have exposed the co-digestion of certain substrates, that of cow dung and water hyacinth is lacking to our knowledge. This is why the present work focuses on optimizing the production of biogas by co-digestion of organic waste (cow dung and water hyacinth).

\section{Work hypothesis:}

Co-digestion with a high percentage of water hyacinth in cow dung optimizes biogas production.

\section{Material and methods}

\section{Material}

\section{Substrate}

The substrate is made up of finely cut water hyacinth (grain size around $5 \mathrm{~cm}$ ), collected in the Nokoué Lake and cow dung collected in Agassa-Godomey. It was introduced into each mini-digester $6 \mathrm{~kg}$ of the water hyacinth - cow dung mixture. Figure 1 and Figure 2 present the chopped water and cow dung used during the experiments.

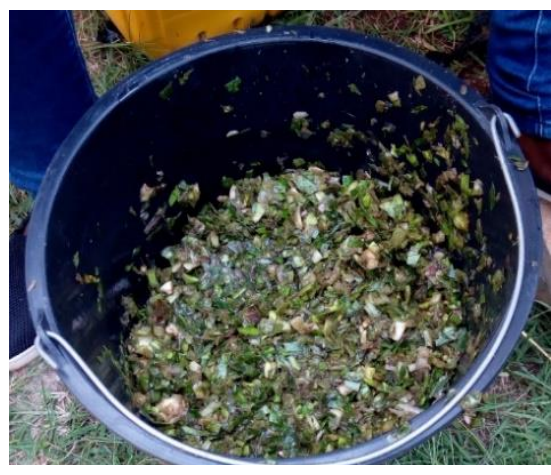

Figure $\mathbf{N}^{\circ} \mathbf{1}$ : Chopped water hyacinth

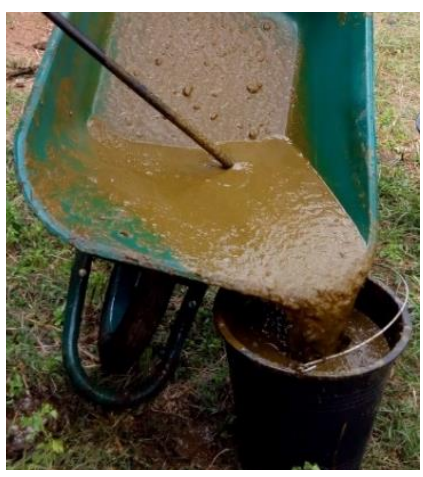

Figure $\mathbf{N}^{\circ} \mathbf{2}$ : Cow dung in pretreatment

\section{Experimental device}

\section{*The digester}

The five digesters are hermetically closed to ensure total anaerobiosis.

During the unfolding of the anaerobic digestion process, the air chamber collects the produced biogas.

\section{* Biogas volume measurement device}

The volume of biogas is measured every day using the displaced liquid method [21] 


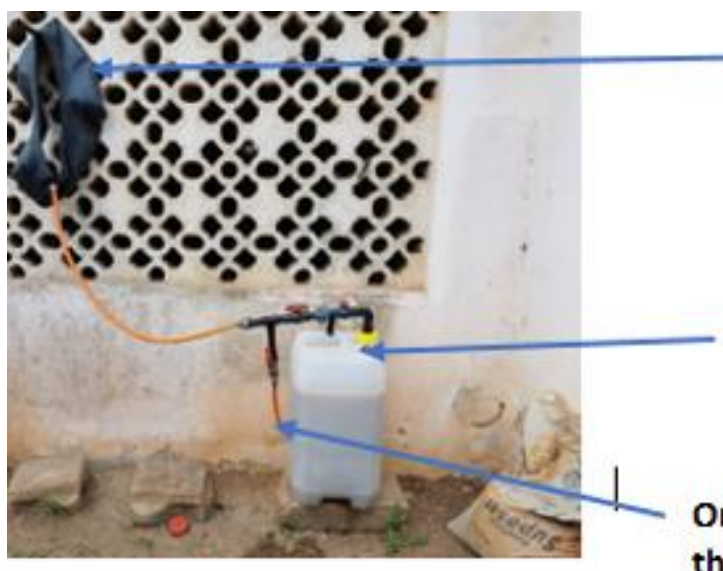

Air chamber containing the produced biogas

Orifice allowing the measurement of the $\mathrm{pH}$ and temperature

Orifice allowing the measurement of the rate of the different gases

Figure N³: Methanization device

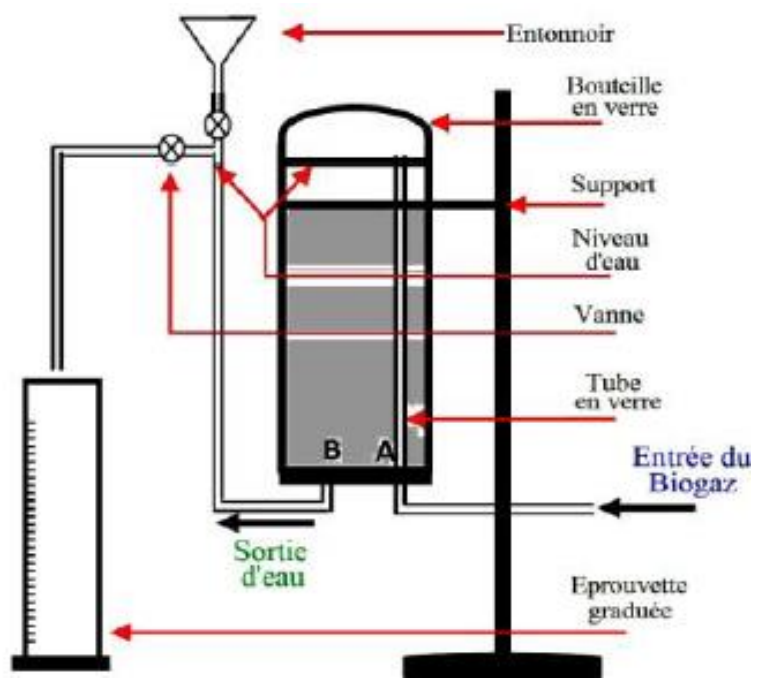

Figure $\mathbf{N}^{\circ} \mathbf{4}$ : Biogas volume measuring system [21]

* The gas analyzer

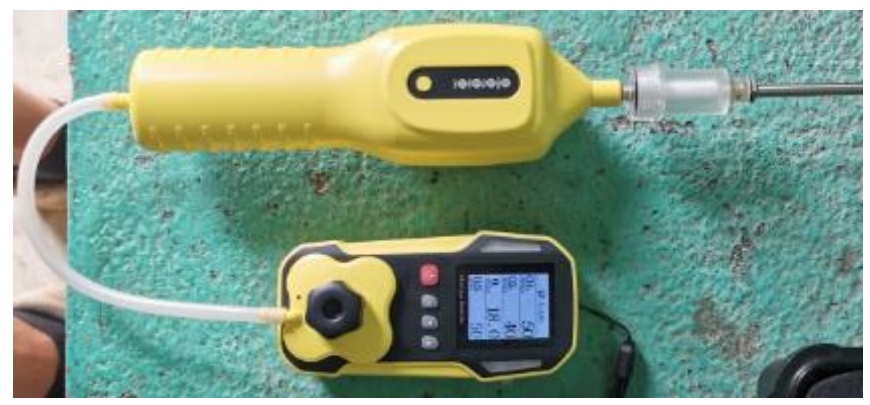

Figure N5: Gas analyzer; IRCD4 model 


\section{Methods}

We introduced into 5 cans with a capacity of 25 liters each, the mixtures of water hyacinth and cow dung in different proportions:

- digester $\mathrm{n}^{\circ} 1(100 \%$ cow dung only);

- digester no. 2 (100\% of the water hyacinth without inoculum);

- digester $n^{\circ} 3$ (50\% of the water hyacinth and $50 \%$ of the cow dung);

- digester $n^{\circ} 4$ ( $75 \%$ of cow dung and $25 \%$ of water hyacinth);

- digester no.5 ( $75 \%$ of the water hyacinth and $25 \%$ of the cow dung).

These mixed remained for 45 days in the digesters.

The percentage of the 4 gases $\left(\mathrm{CH}_{4}, \mathrm{CO}_{2}, \mathrm{O}_{2}, \mathrm{H}_{2} \mathrm{~S}\right)$ is measured daily from the $3^{\text {rd }}$ day after putting the mixtures in the digester by molecular absorption spectrophotometry according to the protocols accompanying the equipment of the IRCD4 brand Biogas Analyzer Manual Instruction.

\section{Results and analysis}

\section{pH variation}

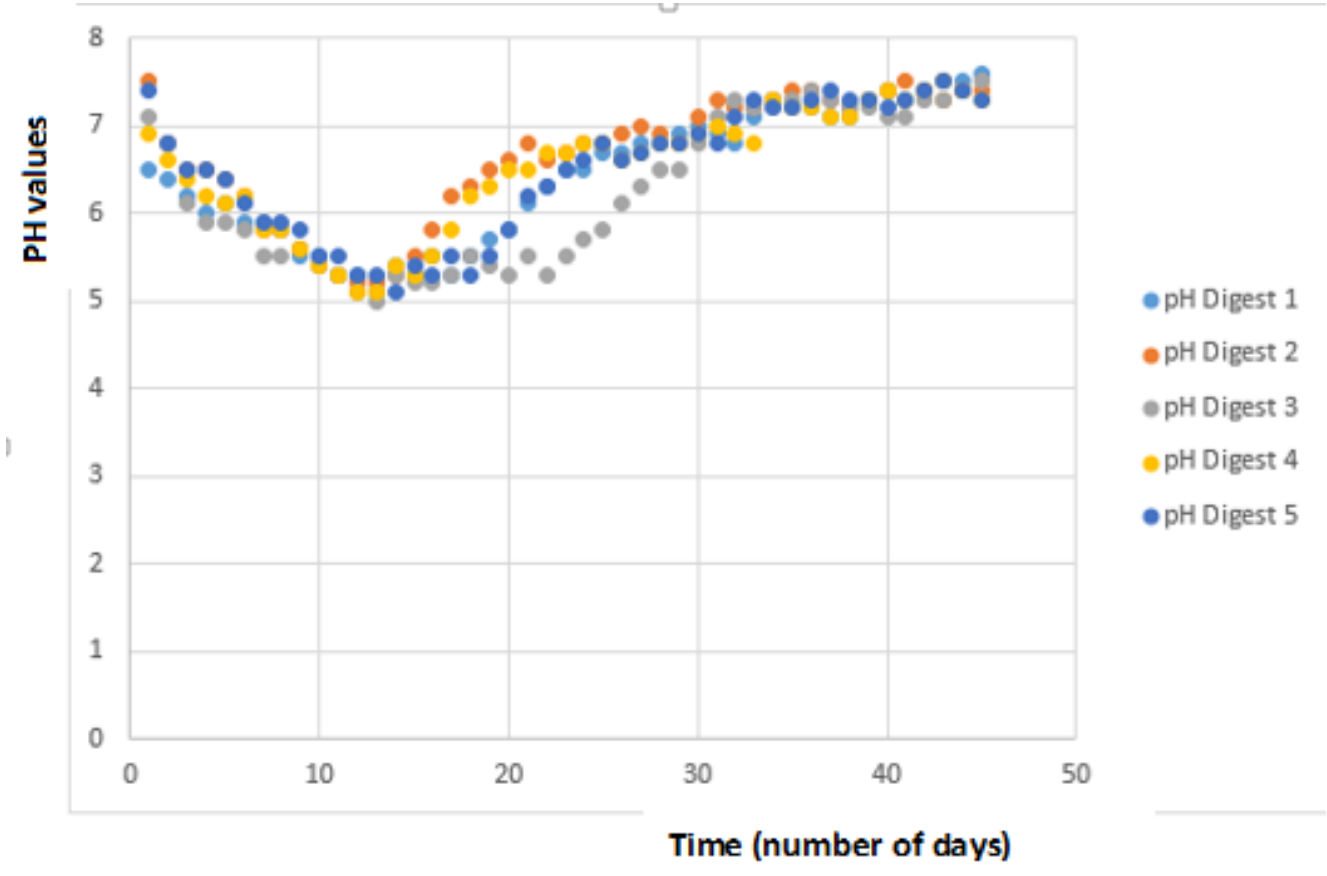

Figure $\mathrm{N}^{\circ}$ 6: $\mathrm{pH}$ variation in the 5 digesters

The figure 6 presents the change in $\mathrm{pH}$ during the experimental process. The $\mathrm{pH}$ values decrease from 5 to 7.5 during the first fifteen days of measurement in all the digesters it is the hydrolysis and acidogenesis phase. From the 16th day, the $\mathrm{pH}$ values begin to increase to reach a maximum value of around 7.5 on the $45^{\text {th }}$ day for the majority of the digesters (acetogenesis and methanogenesis phase).

Adjusting the $\mathrm{pH}$ to around 7 promotes the development of methanogenic bacteria which are responsible for the formation of methane. 


\section{Temperature variation}

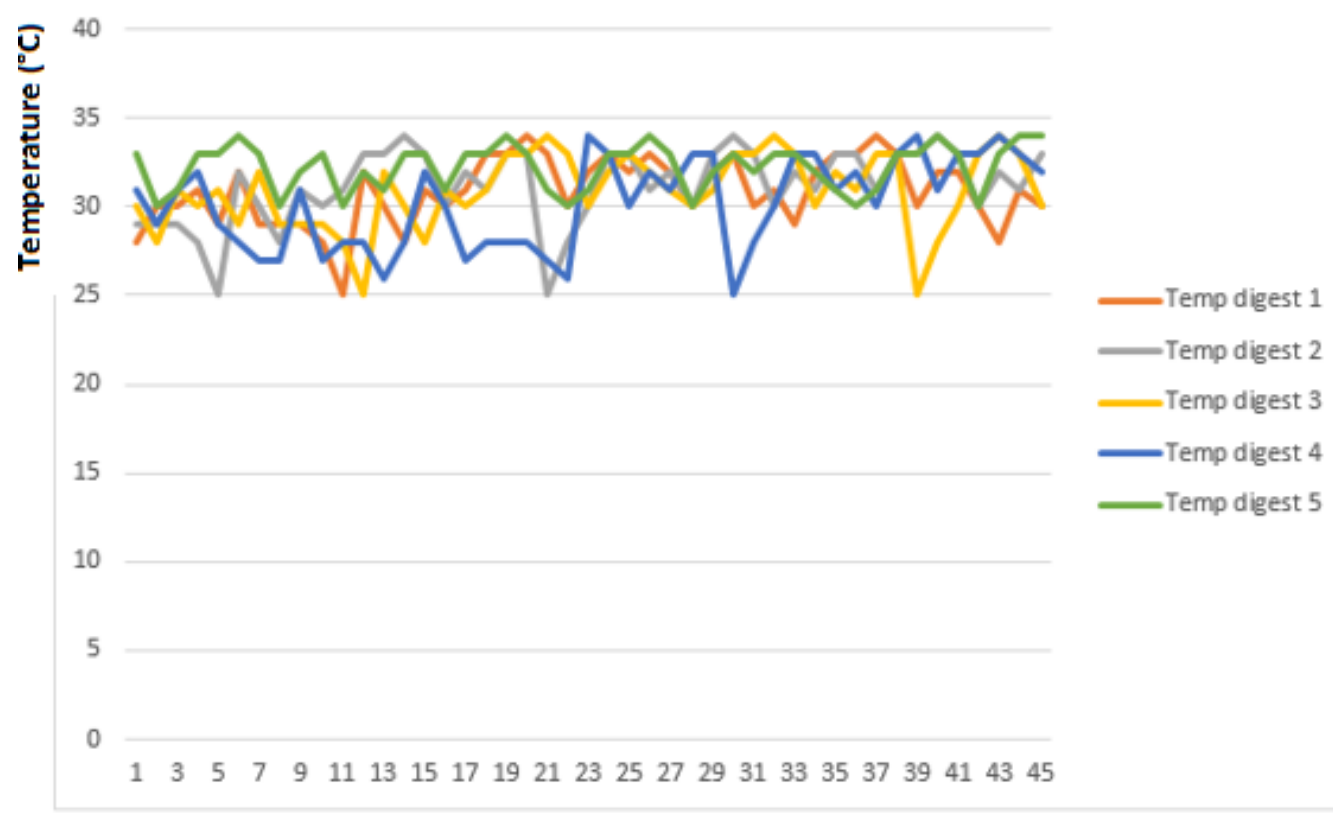

Time (number of days)

Figure $\mathbf{N}^{\circ} 7$ : Temperature variation in the 5 digesters

The figure 7 shows the evolution of temperature during anaerobic digestion in the five digesters. From the measurement period,, the temperature fluctuated around $30^{\circ} \mathrm{C}\left(25^{\circ} \mathrm{C}\right.$ à $35^{\circ} \mathrm{C}$ ) Digestion is then carried out under mesophilic conditions which is one of the main conditions for optimizing anaerobic digestion.

\section{Yield of $\mathrm{CH}_{4}, \mathrm{CO}_{2}, \mathrm{O}_{2}, \mathrm{H}_{2} \mathrm{~S}$ in the biogas}

The percentage of the different gases is read directly on the screen of the biogas analyzer. The Figure below illustrate the change in the level of $\mathrm{CH}_{4}, \mathrm{CO}_{2}, \mathrm{O}_{2}, \mathrm{H}_{2} \mathrm{~S}$ in the biogas produced 


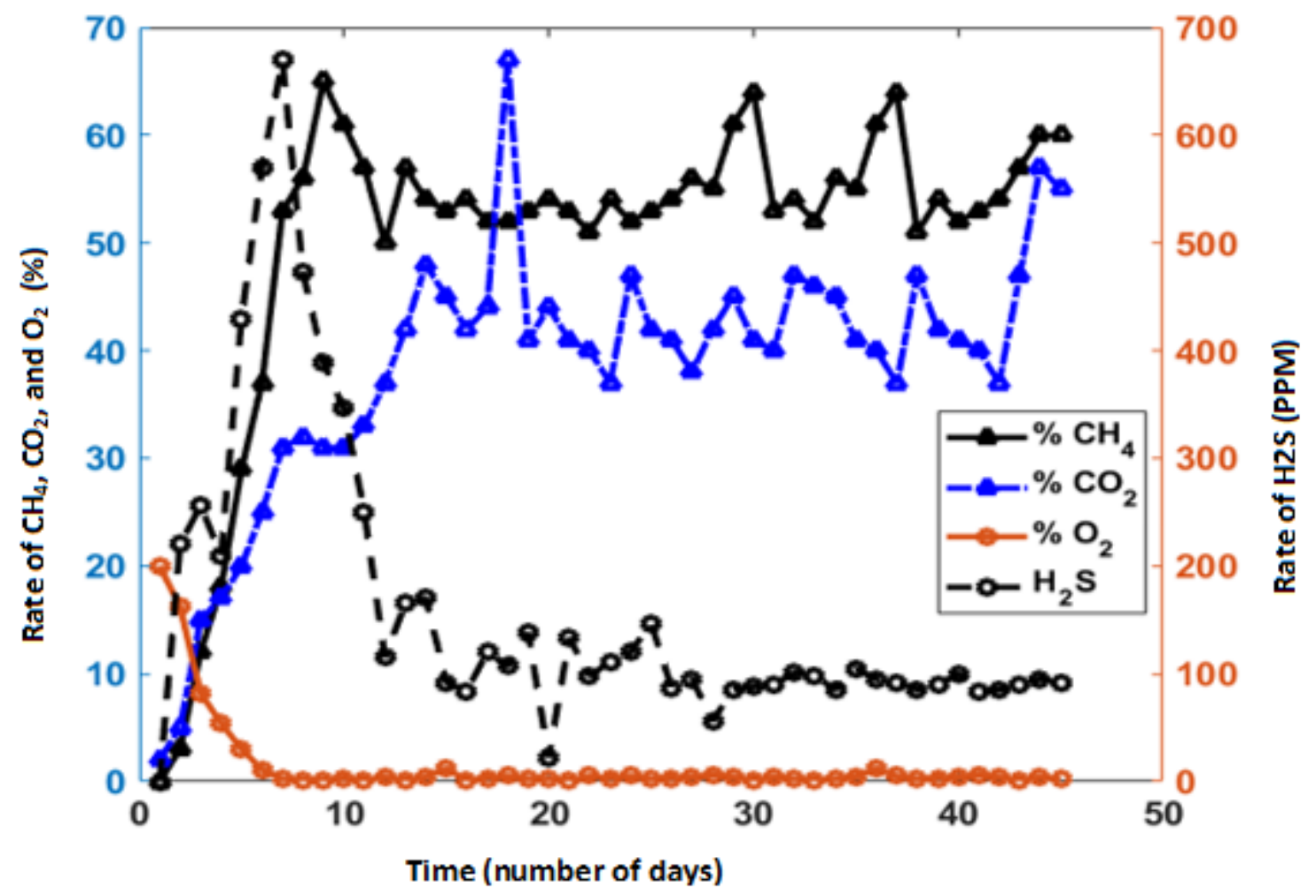

Figure $\mathrm{N}^{\circ} 8$ : Variation in the rate of $\mathrm{CH}_{4}, \mathrm{CO}_{2}, \mathrm{O}_{2}$ and $\mathrm{H}_{2} \mathrm{~S}$ in the biogas produced in digesters $\mathrm{N}^{\circ} 1$ 


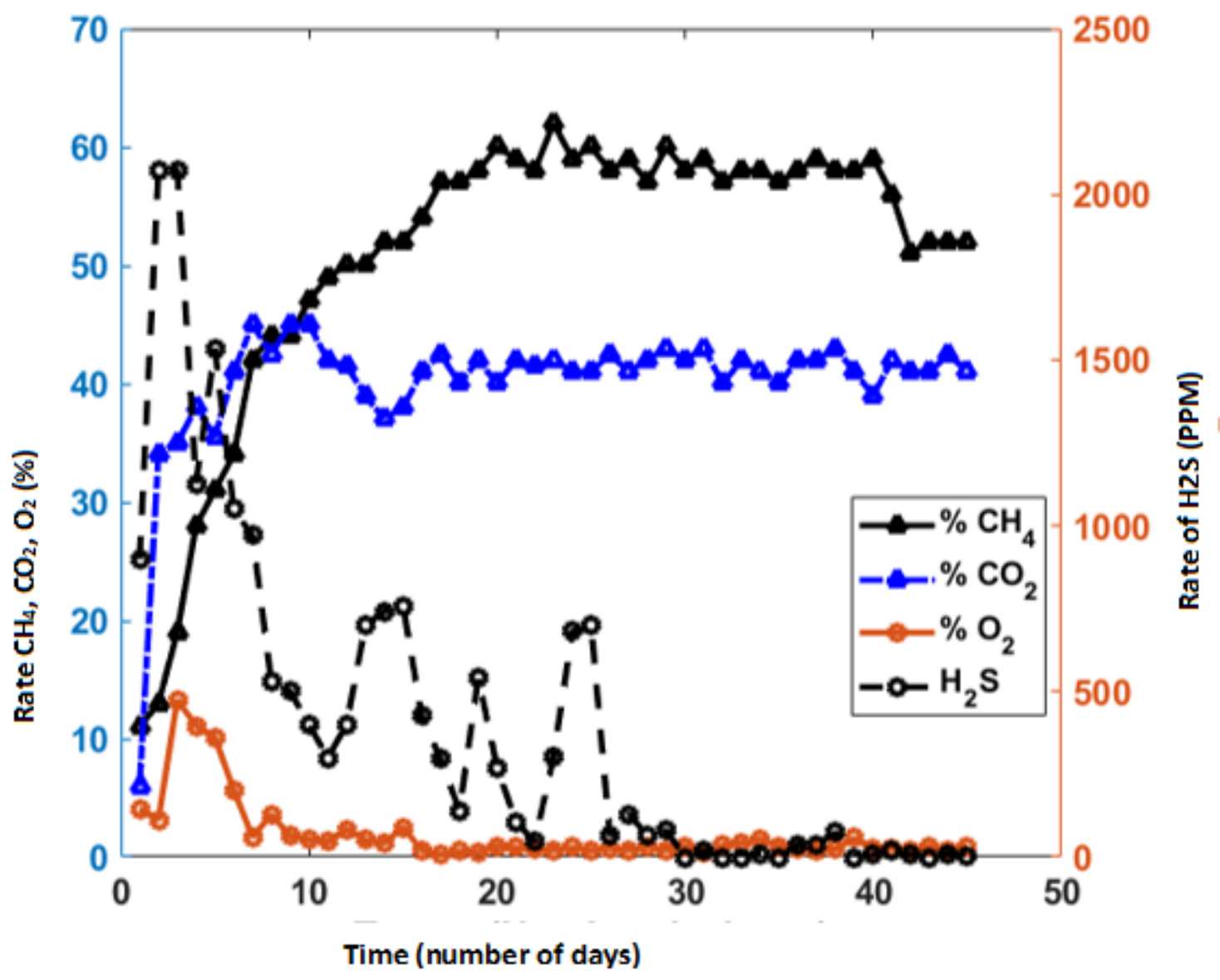

Figure $\mathrm{N}^{\circ}$ : Variation in the rate of $\mathrm{CH}_{4}, \mathrm{CO}_{2}, \mathrm{O}_{2}$ and $\mathrm{H}_{2} \mathrm{~S}$ in the biogas produced in digesters 


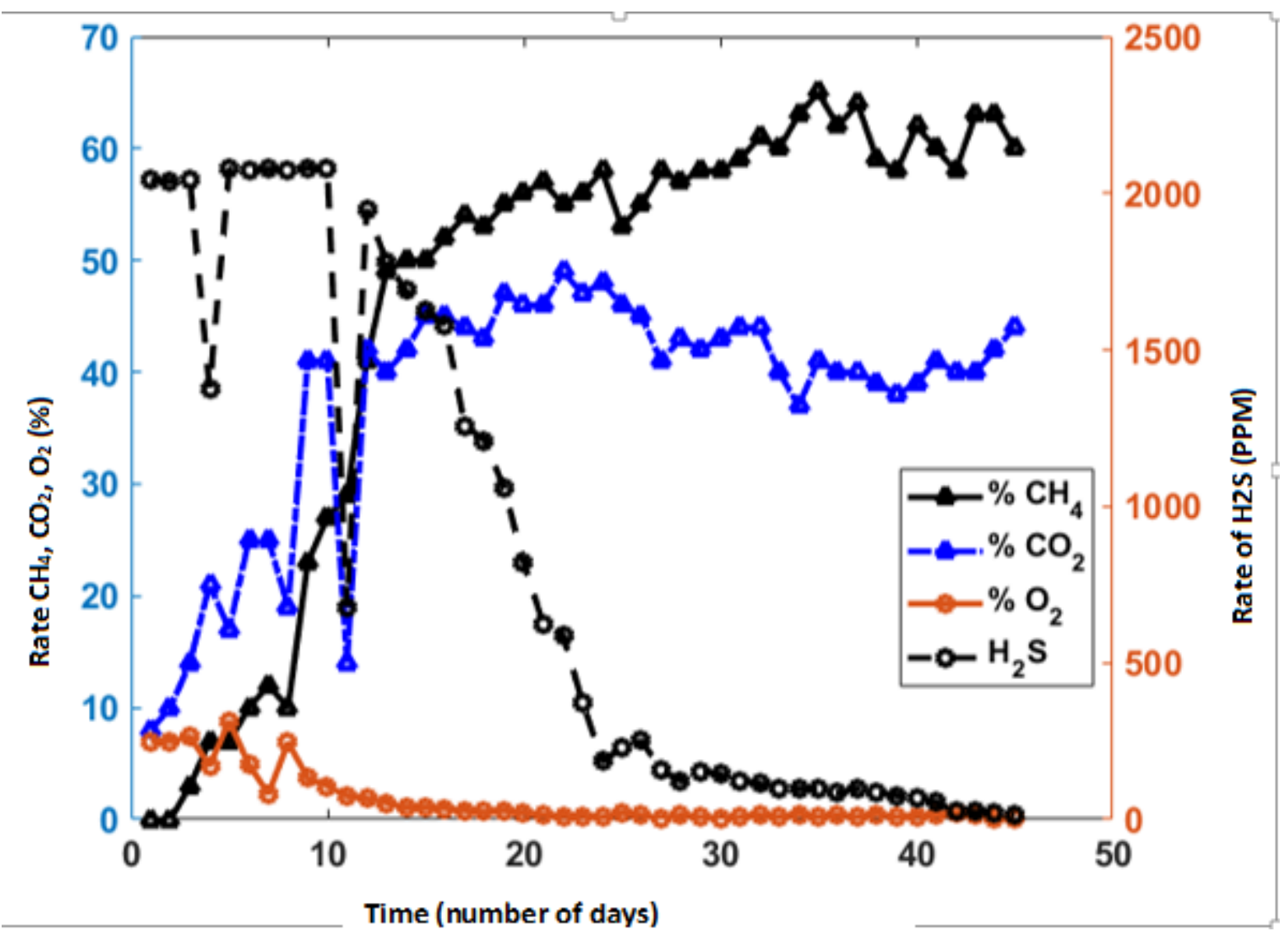

Figure $\mathrm{N}^{\circ}$ 10: Variation in the rate of $\mathrm{CH}_{4}, \mathrm{CO}_{2}, \mathrm{O}_{2}$ and $\mathrm{H}_{2} \mathrm{~S}$ in the biogas produced in digesters $\mathrm{N}^{\circ} 3$

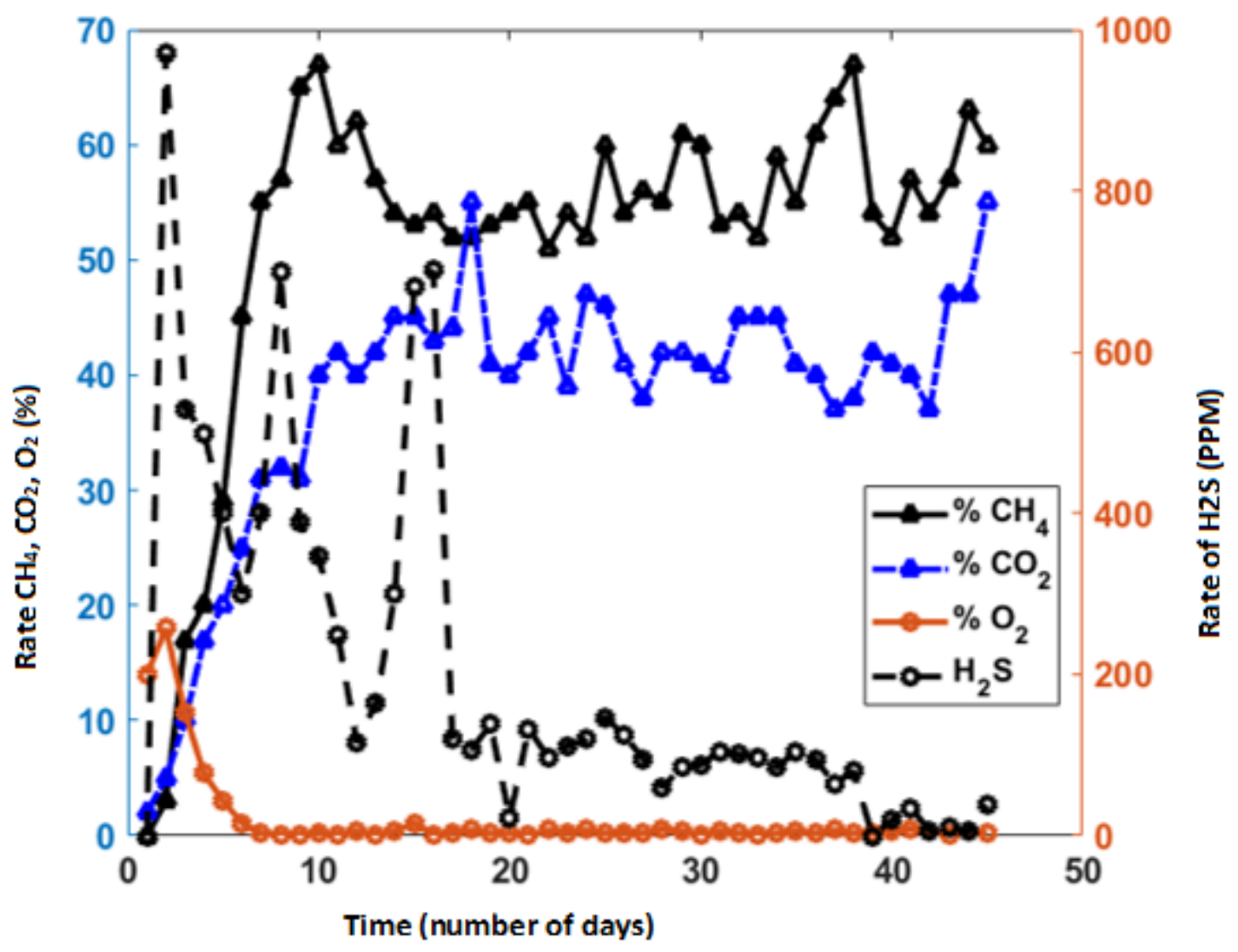

Figure $\mathrm{N}^{\circ}$ 11: Variation in the rate of $\mathrm{CH}_{4}, \mathrm{CO}_{2}, \mathrm{O}_{2}$ and $\mathrm{H}_{2} \mathrm{~S}$ in the biogas produced in digesters $\mathrm{N}^{\circ} 4$ 
In the first 10 days, the methane and carbon dioxide levels increased in all the five digesters showing the production of these gases. But, the $\mathrm{O}_{2}$ level gradually decrease because of the anaerobic reactions in the biodigester. After the 10th day, the oxygen level fluctuated around $0.1 \%$ throughout the experiment. The level of $\mathrm{H}_{2} \mathrm{~S}$ has gradually decreased in all cases until it approaches 0 except in digester $\mathrm{N}^{\circ} 1$ (Figure 8) where the cow dung is $100 \%$. In the digester $\mathrm{N} 1$, after the $10^{\text {th }}$ day, the $\mathrm{CH}_{4}$ level increased before stabilizing around an average value of $60 \%$. In digester $\mathrm{N}^{\circ} 2(100 \%$ water hyacinth) we also notice a gradual increase in the $\mathrm{CH}_{4}$ level till an average of $58 \%$. In digester $3(50 \%$ of the water hyacinth and $50 \%$ of the cow dung) the average level of $\mathrm{CH}_{4}$ is $59 \%$. Methane level also increased in Digester $4(75 \%$ cow dung and $25 \%$ water hyacinth) and Digester 5 ( $75 \%$ water hyacinth and $25 \%$ cow dung). The average methane levels found are $60 \%$ and $70 \%$ respectively. We also notice that the concentration of $\mathrm{CH}_{4}$ and $\mathrm{CO}_{2}$ seems to mirror each other in any case as if the sum of the levels of these two gases were constant.

\section{Variation in the volume of biogas produced}

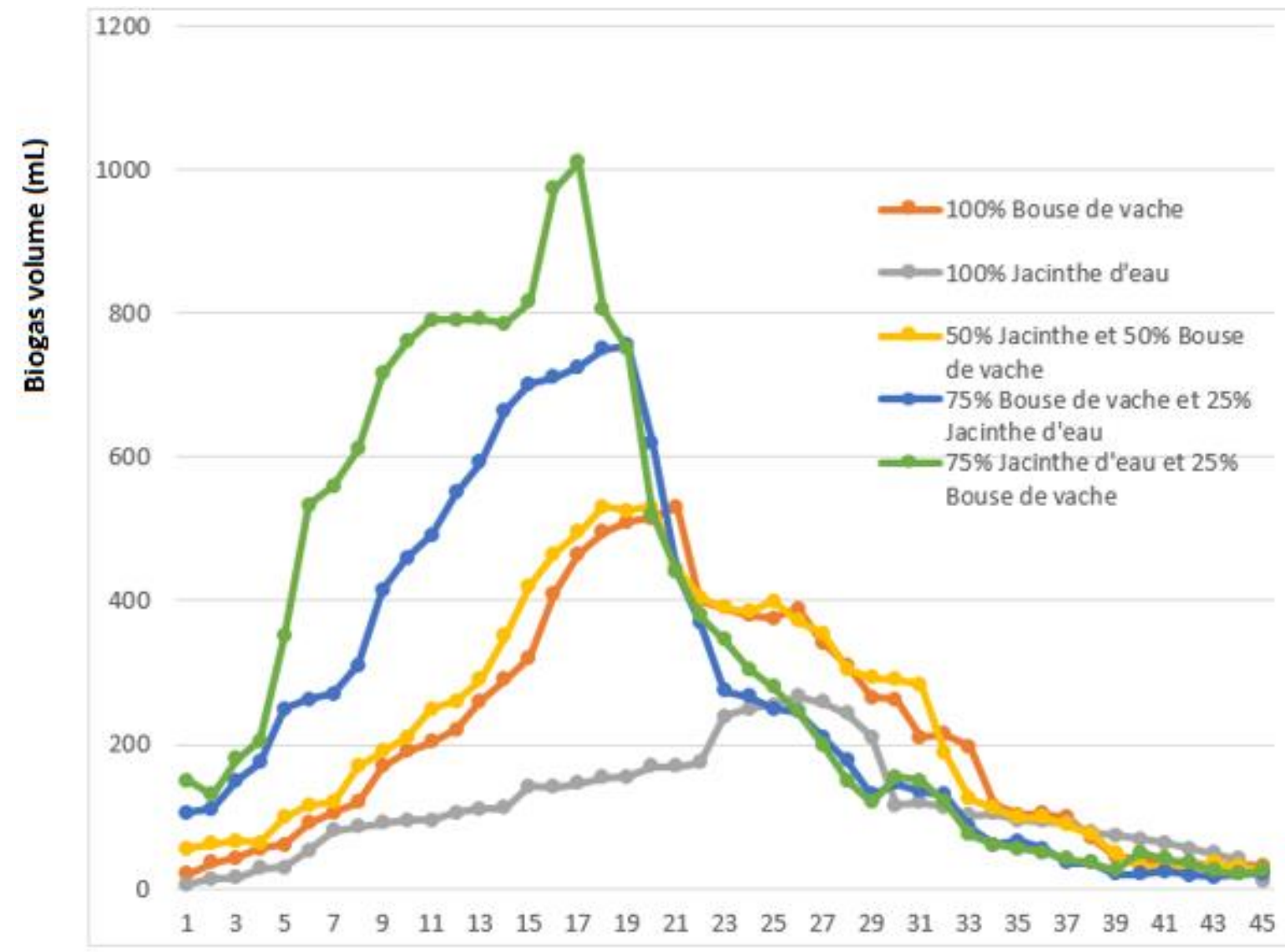

Time (number of days)

Fiaure $\mathrm{N}^{\circ}$ 13: Variation of the volume of bioaas produced in each diaester

Figure $\mathrm{N}^{\circ} 13$ represents the change in the volume of biogas produced as a function of time. During the first ten days, the volume of biogas produced remains low and non-flammable (hydrolysis and acidogenesis phase). After the tenth day, the volume begins to increase variably for each digester. The best results are recorded at the level of digester 5 composed of $75 \%$ water hyacinth and $25 \%$ cow dung, with a maximum value of $1010 \mathrm{~mL}$ on the $20^{\text {th }}$ day; while the low values are recorded at the level of digester 2 composed of $100 \%$ water hyacinth, the highest volume is $266 \mathrm{~mL}$ on the $27^{\text {th }}$ day. Microorganisms have a hard time appearing in Digester 2 (100\% water hyacinth) because there is no inoculum. The microorganisms promoting anaerobic digestion took a long time to appear in the environment. During this time, the other digesters produced biogas. This explains the yield 
obtained at the level of digester No. 2. In digesters containing hyacinth, biogas was produced over a long period because the microorganisms had a large amount of organic matter.. In general, plant materials have a high gas yield because of the carbon inside it, as well as food waste rich in fats and proteins. Animal droppings have a lower energy power, but ensures stability in the culture medium because they provide fresh bacteria and have a strong buffering capacity (maintaining a stable $\mathrm{pH}$ ). The results we have obtained show that in the case of semi-continuous digestion, substrate should be added already from the $15^{\text {th }}$ day.

\section{Total flammable volume produced by each digester}

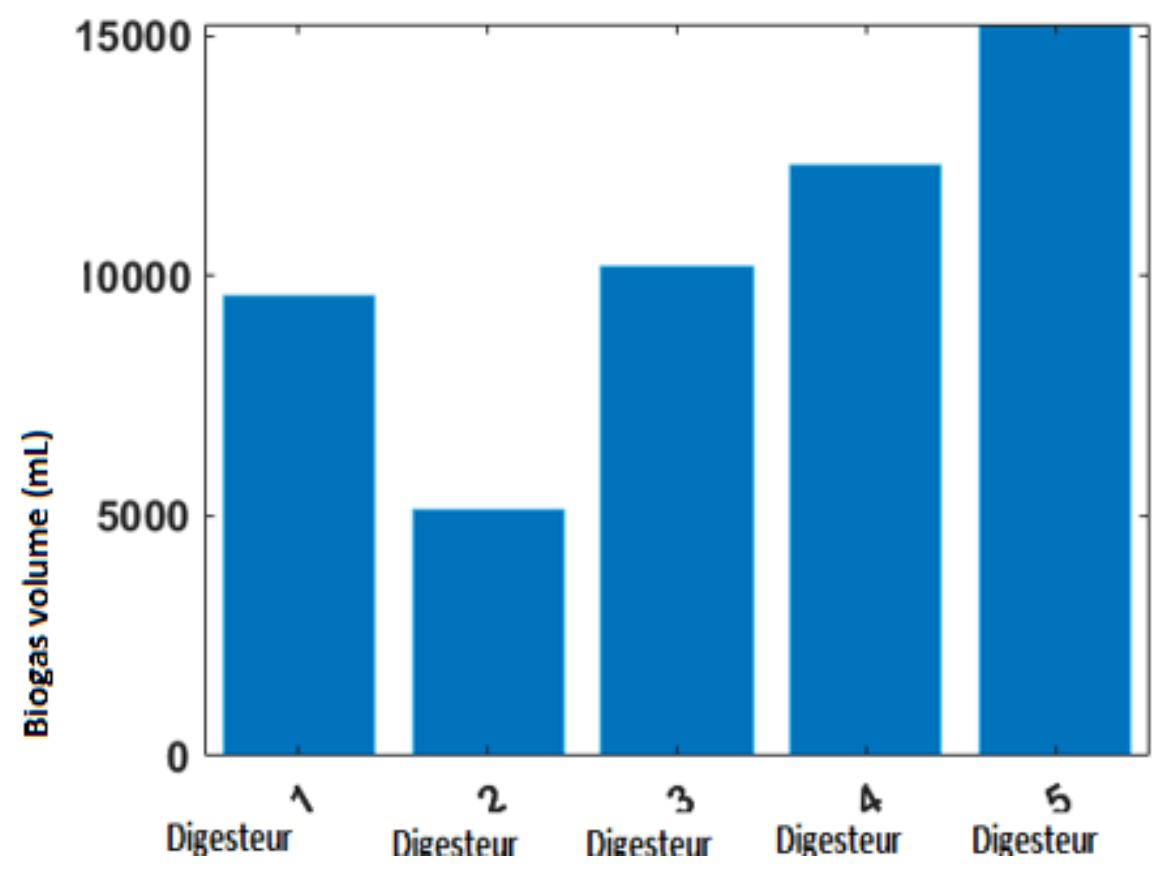

Figure $\mathbf{N}^{\circ} 14$ : Volume of biogas produced in each digester

Figure $\mathrm{N}^{\circ} 14$ shows that the digester 5 has a higher value than the remains of the digesters $(15249 \mathrm{~mL})$, while the digester 2 gave the lowest value of the volume of biogas $(5153 \mathrm{~mL})$. Digesters 2 and 3 have a similar gas production $(9585 \mathrm{~mL}$ and $10189 \mathrm{~mL})$.

\section{Conclusion}

The present study has shown that the biogas yield is greater for a substrate consisting of $75 \%$ water hyacinth and $25 \%$ cow dung with a rate of $70 \%$ methane, whereas for a substrate consisting of $100 \%$ of water hyacinth, biogas production is low with $58 \%$ methane. The initial hypothesis: Co-digestion with a high percentage of water hyacinth in cow dung optimizes biogas production is thus verified. On the other hand, we have found that in the case of semicontinuous digestion, substrate should be added already from the $15^{\text {th }}$ day. The co-digestion of water hyacinth has been shown to be effective. It could no longer be considered as a constraint but as wealth. In the rest of our work, we will size the digester to estimate the amount of energy that could be produced using anaerobic digestion. We will thus estimate the number of households that could be supplied with energy, for example. 


\section{References}

[1] Mata-Alvarez J, Macé S, Llabrés P. Anaerobic digestion of organic solid wastes. An overview of research achievements and perspectives. Bioresource Technology. 2000 08;74(1):3-16. https://doi.org/10.1016/s0960-8524(00)00023-7

[2] Khalid A, Arshad M, Anjum M, Mahmood T, Dawson L. The anaerobic digestion of solid organic waste. Waste Management. 2011 08;31(8):1737-1744.

https://doi.org/10.1016/j.wasman.2011.03.021

[3] Salminen E, Rintala J. Anaerobic digestion of organic solid poultry slaughterhouse waste - a review. Bioresource Technology. 2002 05;83(1):13-26. https://doi.org/10.1016/s09608524(01)00199-7

[4] Astals S, Nolla-Ardèvol V, Mata-Alvarez J. Thermophilic co-digestion of pig manure and crude glycerol: Process performance and digestate stability. Journal of Biotechnology. 2013 07;166(3):97-104. https://doi.org/10.1016/j.jbiotec.2013.05.004

[5] Astals S, Ariso M, Galí A, Mata-Alvarez J. Co-digestion of pig manure and glycerine: Experimental and modelling study. Journal of Environmental Management. 2011 04;92(4):1091-1096. https://doi.org/10.1016/j.jenvman.2010.11.014

[6] Desai M, Patel V, Madamwar D. Effect of temperature and retention time on biomethanation of cheese whey-poultry waste-cattle dung. Environmental Pollution. 1994;83(3):311-315. https://doi.org/10.1016/0269-7491(94)90152-x

[7] Murto M, Björnsson L, Mattiasson B. Impact of food industrial waste on anaerobic codigestion of sewage sludge and pig manure. Journal of Environmental Management. 2004 02;70(2):101-107. https://doi.org/10.1016/j.jenvman.2003.11.001

[8] Somayaji D, Khanna S. Biomethanation of rice and wheat straw. World Journal of Microbiology \& Biotechnology. 1994 09;10(5):521-523. https://doi.org/10.1007/bf00367657

[9] Ghaly A. A comparative study of anaerobic digestion of acid cheese whey and dairy manure in a two-stage reactor. Bioresource Technology. 1996 Oct;58(1):61-72. https://doi.org/10.1016/s0960-8524(96)00105-8

[10] Lehtomäki A, Huttunen S, Rintala J. Laboratory investigations on co-digestion of energy crops and crop residues with cow manure for methane production: Effect of crop to manure ratio. Resources, Conservation and Recycling. 2007 09;51(3):591-609.

https://doi.org/10.1016/j.resconrec.2006.11.004

[11] Gelegenis J, Georgakakis D, Angelidaki I, Mavris V. Optimization of biogas production by co-digesting whey with diluted poultry manure. Renewable Energy. 2007 Oct;32(13):21472160. https://doi.org/10.1016/j.renene.2006.11.015

[12] Davidsson Å, Lövstedt C, la Cour Jansen J, Gruvberger C, Aspegren H. Co-digestion of grease trap sludge and sewage sludge. Waste Management. 2008;28(6):986-992.

https://doi.org/10.1016/j.wasman.2007.03.024

[13] KAPARAJU P, RINTALA J. Anaerobic co-digestion of potato tuber and its industrial byproducts with pig manure. Resources, Conservation and Recycling. 2005 01;43(2):175-188. https://doi.org/10.1016/s0921-3449(04)00119-3

[14] Zupančič GD, Uranjek-Ževart N, Roš M. Full-scale anaerobic co-digestion of organic waste and municipal sludge. Biomass and Bioenergy. 2008 02;32(2):162-167.

https://doi.org/10.1016/j.biombioe.2007.07.006

[15] Alvarez R, Lidén G. Semi-continuous co-digestion of solid slaughterhouse waste, manure, and fruit and vegetable waste. Renewable Energy. 2008 04;33(4):726-734.

https://doi.org/10.1016/j.renene.2007.05.001 
[16] Ağdağ ON, Sponza DT. Co-digestion of mixed industrial sludge with municipal solid wastes in anaerobic simulated landfilling bioreactors. Journal of Hazardous Materials. 2007 02;140(1-2):75-85. https://doi.org/10.1016/j.jhazmat.2006.06.059

[17] Gómez X, Cuetos M, Cara J, Morán A, García A. Anaerobic co-digestion of primary sludge and the fruit and vegetable fraction of the municipal solid wastes. Renewable Energy. 2006 Oct;31(12):2017-2024. https://doi.org/10.1016/j.renene.2005.09.029

[18] Neves L, Oliveira R, Alves M. Anaerobic co-digestion of coffee waste and sewage sludge. Waste Management. 2006 01;26(2):176-181.

https://doi.org/10.1016/j.wasman.2004.12.022

[19] Fezzani B, Cheikh RB. Thermophilic anaerobic co-digestion of olive mill wastewater with olive mill solid wastes in a tubular digester. Chemical Engineering Journal. 2007 08;132(13):195-203. https://doi.org/10.1016/j.cej.2006.12.017

[20] Romano RT, Zhang R. Co-digestion of onion juice and wastewater sludge using an anaerobic mixed biofilm reactor. Bioresource Technology. 2008 02;99(3):631-637.

https://doi.org/10.1016/j.biortech.2006.12.043

[21] Tahri A. Amélioration du rendement de la production de biogaz par co-digestion des déchets organiques (déchets d'abattoir et de volaille). Revue des Energies Renouvelables SIENR Ghardaïa. 2012 January;12:375-380. 